\title{
ВСТРЕЧАЕМОСТЬ ПОЛИМОРФНЫХ ВАРИАНТОВ ГЕНА РЕЦЕПТОРА ВИТАМИНА D У ПАЦИЕНТОВ С ИШЕМИЧЕСКОЙ БОЛЕЗНЬЮ СЕРДЦА С САХАРНЫМ ДИАБЕТОМ 2 ТИПА И БЕЗ НЕГО СРЕДИ НАСЕЛЕНИЯ РЕСПУБЛИКИ ДАГЕСТАН
}

\author{
Омарова Н.Х., Солтаханов Э.М., Маммаев С.Н.
}

\author{
ФГБОУ ВО «Дагестанский государственный медицинский университет» Минздрава России, Махачкала
}

ЦЕЛЬ: оценить встречаемость полиморфизмов гена рецептора витамина D (VDR) и их влияние на статус витамина 25(OH) D у пациентов с сахарным диабетом 2 типа (СД2т), страдающих стенозом коронарных артерий, находившихся на стационарном лечении в «НКО «Дагестанский центр кардиологии и сердечнососУдистой хирургии».

МАТЕРИАЛЫ И МЕТОДЫ: В Исследование включено 120 пациентов с ишемической болезнью сердца (ИБС). Из них 60 в сочетании с СД2т (Гр2) и 60 без СД2т (Гр1). У всех исследованы гликированный гемоглобин ( $\left.\mathrm{HbA}_{1 c}\right)$, глюкоза плазмы натощак (Gl), уровни ЛПНП, ЛПВП, триглицеридов (Трг), кальция, фосфора, щелочной фосфатазы, витамина D3. Определен индекс массы тела (ИМТ), индекс атерогенности (ИА). Оценка поражения коронарных артерий проводилась по степени стеноза левой коронарной артерии (СЛКА) по данным коронарографии. Для генотипирования 3х полиморфных сайтов Fokl (rs2228570) Bsml (rs1544410) Tagal (rs731236) гена VDR использован метод полимеразной цепной реакции (ПЦР) в режиме реального времени (Real Time PCR) фирмы ДНК-технологии.

PЕзУЛЬТАТЫ: сравнительный анализ групп показал, что Гр1 и Гр2 оказались сопоставимы по возрасту (Age) включенных в исследование пациентов. Медиана Age Гр1- $60(56 ; 65)$ и Гр-2 - 61 (56,5;66,5). Стаж заболевания ИБС в 2-х групп был сопоставим между собой Гр1 - 4(2;7) и Гр2 - 3,5(2;6). У пациентов Гр1 и Гр2 также не было выявлено значимых различий по показателю ИА 4,3(3,4;5,1) и 4,6(3,2;5,7) соответственно ( $>>0,05)$, однако в обоих группах был высоким (>3,5). Уровень Трг, статистически значимо различался между Гр1 1,9 $(1,5 ; 2,5)$ и Гр2 2,8(1,7;4,1) $\left(\mathrm{P}_{02}=0,02\right)$. При сравнении показателя $\mathrm{HbA}_{1 c}$ выявлены значимые различия среди Гр1 и Гр2 ( $\left.\mathrm{P}_{02}=0,0001\right)$. При сравнении показателя $25(\mathrm{OH}) \mathrm{D}$ в Гр1 - 14,2(11,8;19) и Гр2 $16,1(11 ; 21,4)$ значимых различий выявлено не было, однако в обеих группах отмечался его дефицит. В Гр1 выявлена положительная корреляционная связь между Трг и ИА, $\mathrm{HbA}_{1 с}$ и СЛКА, а также выявлена отрицательная корреляционная связь между ЩФ и ИМТ, между 25(ОН)D и глюкозой. В Гр2 выявлена положительная корреляционная связь между Трг и ИА, между $\mathrm{HbA}_{1 с}$ и глюкозой, ЩФ и СЛКА, а также отрицательная корреляционная связь между 25(OH)D и $\mathrm{HbA}_{1 c}$. При сравнении распределения генотипов Bsml (rs1544410) гена VDR, в Гр1 и Гр2, частота гетерозиготного генотипа GA выше в Гр2 (49,2 и 430,0), гомозиготный генотип GG встречается чаще в Гр1 (45,5\% и 41,0\% соответственно). При сравнении распределения генотипов Fokl (rs2228570) гена VDR, Гр1 и Гр2, частота гомозиготного генотипа GG выше в Гр1 (58,2\%), в Гр2 процент носителей гомозиготы АА преобладает по сравнению с Гр1 (8,2\% и 3,6\%). При сравнении распределения генотипов Tagal (rs731236) гена VDR, частота гетерозиготного генотипа TC выше в Гр2 выше чем в Гр1, $(47,5$ и 34,5$)$ однако в Гр1 носители гомозиготы ТТ встречаются чаще $(56,4 \%)$ чем в Гр2 (44,3\%).

Выводы: по результатам нашего исследования можно сделать вывод, что в группе Гр1 чаще встречаются гомозиготный генотип GG полиморфизма гена VDR типа Bsml и Fokl, Tagal (гомозиготный вариант TT), а у пациентов в Гр2 чаще встречаются гомозиготный генотип AA полиморфизма Fokl и гетерозиготные генотипы GA и TC полиморфизмов Bsml и Tagal соответственно, а также выявлена отрицательная корреляционная связь между уровнем ВитD25(OH) и $\mathrm{HbA}_{1 c^{\circ}}$

КЛЮЧЕВЫЕ СЛОВА: сахарный диабет; витамин D; атеросклероз; инфаркт миокарда. 